\title{
Desain Pembelajaran Matematika Berbasis Gamifikasi untuk Meningkatkan Minat Belajar Siswa
}

\author{
Clara Ayu Mia Permata ${ }^{1}$, Yosep Dwi Kristanto ${ }^{2 *}$ \\ 1,2Program Studi Pendidikan Matematika, Universitas Sanata Dharma, Yogyakarta, \\ Indonesia; ${ }^{1}$ larapermata14@gmail.com; ${ }^{2 *}$ yosepdwikristanto@usd.ac.id
}

Info Artikel: Dikirim: 20 Juli 2020; Direvisi: 11 September 2020; Diterima: 21 September 2020 Cara sitasi: Permata, C. A. M., \& Kristanto, Y. D. (2020). Desain Pembelajaran Matematika Berbasis Gamifikasi untuk Meningkatkan Minat Belajar Siswa. JNPM (Jurnal Nasional Pendidikan Matematika), 4(2), 279-291.

\begin{abstract}
Abstrak. Minat merupakan salah satu faktor penting yang mempengaruhi keberhasilan belajar siswa. Akan tetapi, tidak jarang dijumpai siswa yang memiliki minat rendah dalam pembelajaran matematika. Salah satu strategi yang dapat digunakan untuk meningkatkan minat siswa dalam pembelajaran matematika adalah gamifikasi. Penelitian ini bertujuan untuk mengembangkan perangkat pembelajaran matematika berbasis gamifikasi untuk dapat meningkatkan minat belajar siswa. Penelitian ini menggunakan metode pengembangan. Subjek dalam penelitian ini sebanyak 18 siswa kelas XI SMA di Banguntapan, Yogyakarta. Hasil menunjukkan bahwa perangkat pembelajaran yang dikembangkan memiliki rerata validitas yang sangat tinggi, meningkatkan minat belajar siswa dengan rerata peningkatan 3,30\%, dan instrumen asesmennya menyediakan tantangan dalam kategori sedang, sehingga perangkat pembelajaran tersebut efektif dan memiliki kualitas baik. Sehingga gamifikasi dapat digunakan sebagai salah satu strategi untuk meningkatkan minat belajar siswa dalam pembelajaran matematika.
\end{abstract}

Kata Kunci: Research and Development, Gamifikasi, Kahoot!, Quizizz, dan Minat Belajar.

\begin{abstract}
Interest is one of the crucial factors that influence student learning success. However, it is not uncommon to find students who have a low interest in learning mathematics. One of the strategies that can be used to increase students' interest in learning mathematics is gamification. This study aims to develop gamification-based mathematics learning tools to increase student interest in learning. This study uses a development method. The subjects in this study were 18 students of class XI, one of High School in Banguntapan, Yogyakarta. The results show that the learning tools developed have a very high average validity, increase student interest in learning with an average increase of $3.30 \%$, and the assessment instrument provides a challenge in the moderate category so that the learning tool is useful and has good quality. So that gamification can be used as a strategy to increase student interest in learning mathematics.
\end{abstract}

Keywords: Research and Development, Gamification, Kahoot!, Quizizz, Interest. 


\section{Pendahuluan}

Minat merupakan salah satu faktor penting yang mempengaruhi keberhasilan belajar siswa. Dengan minat yang baik, siswa cenderung dapat mengarahkan perhatiannya ke topik atau aktivitas pembelajaran yang disediakan (Ainley, Hidi, \& Berndorff, 2002). Selain itu, siswa akan lebih terdorong untuk membuat tujuan dan standar sendiri, serta menggunakan regulasi dirinya untuk mencapai tujuan dan standar tersebut dalam proses pembelajarannya (O'Keefe \& Linnenbrink-Garcia, 2014; Senko \& Harackiewicz, 2002). Lebih jauh, ketika siswa memiliki minat yang tinggi, siswa tersebut akan memberikan usaha yang lebih besar dalam proses pembelajaran (Deci, Koestner, \& Ryan, 2001) dan pada akhirnya akan berpengaruh terhadap hasil belajarnya (Koller, Baumert, \& Schnabel, 2001; Tosto, Asbury, Mazzocco, Petrill, \& Kovas, 2016).

Minat seorang siswa dapat merujuk pada dua hal, yaitu minat situasional dan individual (Hidi \& Renninger, 2006). Minat situasional dapat muncul secara sementara setelah diberikan stimulus tertentu. Minat situasional ini terdiri dari dua fase, yaitu fase ketika minat tersebut dipantik dan fase berikutnya ketika minat tersebut dijaga (Harackiewicz, Barron, Tauer, Carter, \& Elliot, 2000). Berbeda dengan minat situasional, minat individual terhadap objek tertentu (misalnya mata pelajaran matematika) lebih bersifat tetap dan mendalam (Krapp, 1999). Minat individual ini juga terdiri dari dua fase, yaitu fase ketika minat individual muncul dan fase ketika minat tersebut sudah berkembang dengan baik (Renninger, 2000). Dengan demikian, total terdapat empat fase yang dapat digunakan untuk mengembangkan minat siswa dalam pembelajaran.

Fase-fase untuk mengembangkan minat tersebut penting untuk dipahami dan diimplementasikan oleh guru atau pendidik ketika berhadapan dengan siswa yang memiliki minat belajar rendah. Minat belajar yang rendah ini tidak jarang ditemukan di dalam pembelajaran matematika (Belbase, 2013; Fimansyah, 2015). Untuk mengembangkan minat yang rendah di dalam pembelajaran matematika ini, pendidik dapat (a) membantu siswa menjaga perhatiannya pada suatu aktivitas pembelajaran, meskipun aktivitas tersebut menantang; (b) memberi kesempatan kepada siswa untuk mengajukan pertanyaan yang mewujudkan rasa ingin tahunya; dan (c) memilih atau mengembangkan sumber belajar yang memantik pemecahan masalah dan pembuatan strategi (Hidi \& Renninger, 2006). Pada tahapan awal perkembangan minat belajar siswa, peran guru sangat penting dalam membantu mereka untuk memiliki pandangan yang positif dalam pembelajaran matematika. Hal ini dapat dilakukan dengan berbagai macam 
cara, misalnya dengan aktivitas-aktivitas pembelajaran berbantuan komputer yang menarik (Millis, Forsyth, Wallace, Graesser, \& Timmins, 2017) dan aktivitas-aktivitas yang membangun rasa kepemilikan kompetensi (Schraw, Flowerday, \& Lehman, 2001).

Gamifikasi merupakan salah satu strategi yang dapat diterapkan untuk mengembangkan minat belajar siswa dalam pembelajaran matematika. Gamifikasi didefinisikan sebagai penggunaan elemen-elemen desain gim dalam konteks-konteks bukan gim (Deterding, Dixon, Khaled, \& Nacke, 2011). Konteks bukan gim tersebut salah satunya adalah pembelajaran matematika. Elemen-elemen desain gim dalam gamifikasi bermacammacam, di antaranya adalah poin, lencana, papan skor, dan tantangan (Kristanto, 2020). Elemen-elemen tersebut digunakan sebagai mekanisme pemenuhan kebutuhan dasar siswa terkait kompetensi, otonomi, dan relasi (Deci \& Ryan, 1985; Sailer, Hense, Mayr, \& Mandl, 2017). Untuk mengimplementasikan gamifikasi tersebut ke dalam pembelajaran matematika, para pendidik dan peneliti biasanya menggunakan kuis daring sebagai pintu masuknya (Sailer \& Sailer, 2020).

Ada beberapa kuis daring yang dapat digunakan untuk melakukan gamifikasi dalam pembelajaran matematika. Dua kuis daring yang sering digunakan adalan Kahoot! dan Quizizz. Kedua jenis kuis daring ini menawarkan beberapa fitur yang dapat meningkatkan kualitas pembelajaran siswa. Pertama, dua jenis kuis tersebut dapat memberikan umpan balik secara langsung kepada siswa dengan menggunakan poin. Umpan balik langsung seperti ini dapat membangkitkan persepsi positif siswa terhadap pembelajaran yang dialaminya (Alexander, 2017). Kedua, papan skor atau papan peringkat yang disediakan oleh dua jenis kuis tersebut memberikan lingkungan kompetisi bagi siswa. Lingkungan belajar seperti ini potensial untuk mendorong keterlibatan dan partisipasi aktif siswa dalam pembelajaran (Burguillo, 2010; Chen \& Chiu, 2016).

Meskipun sudah cukup banyak penelitian yang telah menyelidiki kuis daring Kahoot! atau Quizizz, tetapi masih sedikit yang menggunakan kedua kuis tersebut di dalam penelitian pembelajaran matematika dengan konteks Indonesia. Basuki \& Hidayati (2019) telah berupaya untuk meneliti penggunaan kedua jenis kuis tersebut dengan konteks Indonesia. Akan tetapi, penelitian tersebut tidak dilakukan pada pembelajaran matematika. Selain itu, penelitian tersebut berfokus pada persepsi mahasiswa terhadap dua kuis daring tersebut. Dengan demikian, artikel ini akan menawarkan keunikan dalam hal desain maupun konteks penelitiannya. 
Berdasarkan pentingnya minat siswa serta peluang penggunaan Kahoot! dan Quizizz dalam pembelajaran matematika untuk meningkatkan minat belajar siswa, tujuan penelitian ini adalah untuk mengembangkan perangkat pembelajaran matematika berbasis gamifikasi dengan menggunakan kuis daring Kahoot! dan Quizizz. Penggunaan kedua jenis kuis tersebut selain ditujukan sebagai alat asesmen, tetapi juga digunakan sebagai aktivitas pembelajaran menyenangkan yang dapat membangkitkan minat belajar siswa. Oleh karena itu, pertanyaan penelitian yang akan dijawab dalam penelitian ini adalah tentang bagaimana kualitas perangkat pembelajaran yang telah dikembangkan ditinjau dari minat belajar siswa.

\section{Metode}

Penelitian ini menggunakan metode pengembangan dengan 10 tahapan, yaitu identifikasi potensi dan masalah, pengumpulan data, desain produk, revisi desain produk, ujicoba produk, revisi produk, ujicoba pemakaian, revisi produk, dan pembuatan produk secara masal (Sugiyono, 2011). Akan tetapi, dalam penelitian ini hanya mengembangkan sampai pada tahap keenam, yaitu tahap ujicoba karena penelitian ini bertujuan untuk merancang dan mengembangkan suatu produk perangkat pembelajaran berbasis gamifikasi melalui Kahoot! dan Quizizz yang berkualitas baik dari segi minat belajar siswa.

Subjek penelitian ini adalah 18 siswa SMA Kelas XI IPA dan XI IPS di salah satu SMA swasta di Banguntapan, Yogyakarta. Pemilihan subjek tersebut didasarkan pada identifikasi potensi dan masalah yang telah dilakukan. Berdasarkan identifikasi potensi dan masalah tersebut, kami menemukan bahwa di kedua kelas tersebut membutuhkan pemanfaatan teknologi untuk meningkatkan minat belajar siswanya. Teknik pengumpulan data dalam penelitian ini berupa validasi perangkat pembelajaran, penyebaran kuesioner minat belajar siswa, serta ujicoba soal asesmen melalui Kahoot! dan Quizizz. Validasi perangkat pembelajaran digunakan sebagai acuan untuk mengukur validitas perangkat pembelajaran yang dikembangkan. Penyebaran kuesioner digunakan untuk mengetahui minat belajar siswa, baik sebelum maupun setelah melakukan aktivitas Kahoot! dan Quizizz. Ujicoba soal digunakan untuk melihat tingkat kesukaran butir-butir soal yang telah dikembangkan.

Kualitas perangkat pembelajaran yang dikembangkan ditentukan berdasarkan validitas perangkat pembelajaran tersebut, minat belajar siswa, dan tingkat kesukaran setiap butir soal yang dikembangkan (Kristanto, 
Amin, \& Khabibah, 2016). Kualitas perangkat pembelajaran dapat dikatakan memenuhi standar baik jika validitas perangkat pembelajaran memiliki standar minimal valid, adanya peningkatan minat belajar siswa, dan tingkat kesukaran setiap butir soal berada pada berkategori sedang.

Hasil validasi ahli terhadap perangkat pembelajaran yang dikembangkan dianalisis dengan menggunakan rerata persentase. Skor yang diberikan oleh para validator pada masing-masing perangkat pembelajaran dibandingkan dengan skor maksimumnya untuk mendapatkan persentase dan kemudian persentase nilai para validator tersebut ditentukan reratanya.

Analisis peningkatan minat belajar masing-masing siswa dilakukan dengan menentukan selisih skor minat belajar siswa setelah dan sebelum melakukan aktivitas pembelajaran melalui Kahoot! dan Quizizz. Selisih skor tersebut kemudian dibandingkan dengan skor minat belajar siswa sebelum melakukan aktivitas Kahoot! dan Quizizz dan dikalikan 100\% untuk mendapatkan persentase peningkatan minat belajar setiap siswa.

Tingkat kesukaran setiap butir soal dalam kuis daring Kahoot! dan Quizizz ditentukan dengan menggunakan pendekatan empiris, yaitu dengan membagi banyaknya siswa yang menjawab benar soal tersebut dengan total banyaknya siswa kemudian dikalikan dengan 100\% untuk mendapatkan skor dalam persentase.

\section{Hasil dan Pembahasan}

Berdasarkan validasi perangkat pembelajaran yang divalidasi oleh satu guru matematika dan dua dosen pendidikan matematika, tampak bahwa perangkat pembelajaran yang telah dibuat (yaitu RPP, pretest, postest, dan kuis daring) sudah sangat valid atau dapat digunakan tanpa revisi. Secara detail, hasil validasi ini dapat dilihat pada Tabel 1 berikut.

Tabel 1. Hasil Validasi Perangkat Pembelajaran

\begin{tabular}{lll}
\hline $\begin{array}{l}\text { Perangkat } \\
\text { Pembelajaran }\end{array}$ & $\begin{array}{l}\text { Nilai Rata- } \\
\text { rata }\end{array}$ & Tingkat Validitas \\
\hline RPP & $82,22 \%$ & Sangat Valid, atau dapat digunakan tanpa revisi \\
Soal pretest & $86,67 \%$ & Sangat Valid, atau dapat digunakan tanpa revisi \\
Soal posttest & $91,67 \%$ & Sangat Valid, atau dapat digunakan tanpa revisi \\
Lembar kuesioner & $98,57 \%$ & Sangat Valid, atau dapat digunakan tanpa revisi \\
minat belajar siswa & & \\
\hline
\end{tabular}

Tabel 1 menunjukkan bahwa lembar kuesioner minat belajar siswa yang dikembangkan memiliki rata-rata tingkat validitas yang sangat valid atau 
dapat digunakan tanpa revisi. Dengan demikian, lembar kuesioner ini sudah layak untuk digunakan sebagai pengukur minat belajar siswa, baik sebelum maupun setelah menggunakan kuis daring Kahoot! dan Quizizz.

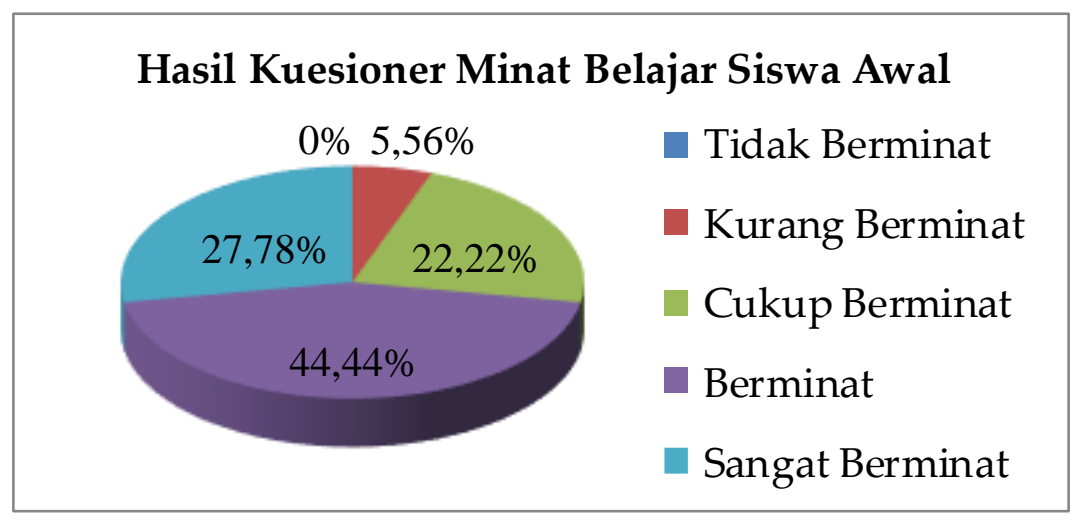

Gambar 1. Hasil Kuesioner Minat Belajar Siswa Awal

Gambar 1 menunjukkan kategori minat belajar siswa sebelum mengerjakan kuis daring melalui Kahoot! dan Quizizz sudah cukup baik, persentase minat lebih dari $50 \%$.

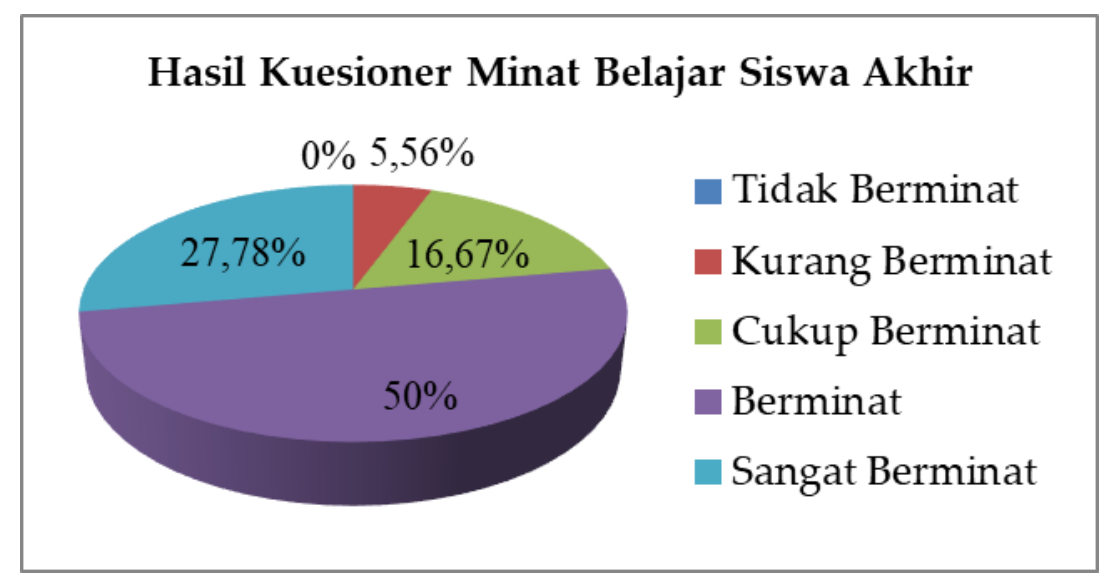

Gambar 2. Hasil Kuesioner Minat Belajar Siswa Akhir

Gambar 2 menunjukkan bahwa kategori minat belajar siswa setelah mengerjakan kuis daring melalui Kahoot! dan Quizizz. Tampak bahwa minat belajar siswa setelah mengalami dua kuis daring tersebut lebih mengumpul pada kategori berminat. Untuk mengetahui adanya peningkatan minat belajar, persentase peningkatan minat belajar masing-masing siswa dihitung dan diperoleh reratanya $M=3,30 \%$ (dengan simpangan baku $S D=12,71 \%$ ). Dengan demikian, dapat disimpulkan bahwa secara umum terdapat peningkatan minat belajar siswa setelah melakukan pengerjaan kuis daring melalui Kahoot! dan Quizizz. Hasil ini sejalan dengan beberapa penelitian 
yang menggunakan Kahoot! dan Quizizz untuk meningkatkan minat belajar siswa (Licorish, Owen, Daniel, \& George, 2018; Zhao, 2019).

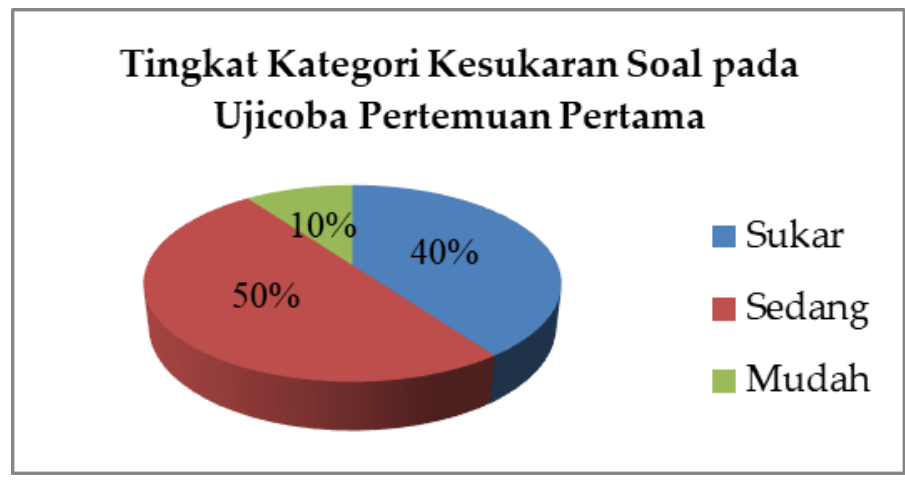

Gambar 3. Hasil Tingkat Kesukaran Soal pada Pertemuan Pertama

Gambar 3 menunjukkan hasil pengerjaan semua siswa di pertemuan pertama, sebanyak 50\% soal yang disusun masuk ke dalam tingkat kesukaran kategori sedang, sedangkan soal-soal lainnya masuk ke dalam kategori sukar dan mudah.

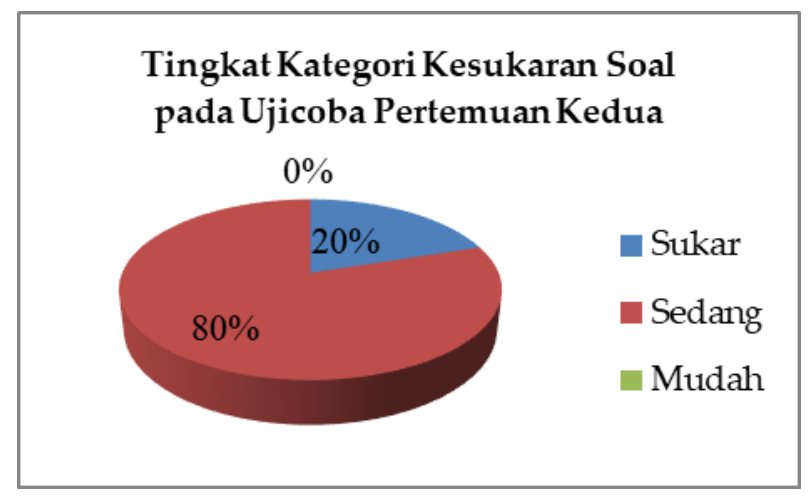

Gambar 4. Hasil Tingkat Kesukaran Soal pada Pertemuan Kedua

Gambar 4 menunjukkan persentase kategori tingkat kesukaran soal-soal yang dikembangkan pada pertemuan kedua. Tampak bahwa sebagian besar soalnya $(80 \%)$ berada pada kategori sedang dan tidak ada soal yang masuk ke dalam kategori mudah.

Hasil yang cukup menarik dijumpai pada tingkat kesukaran soal di pertemuan ketiga. Dari 10 soal yang diujikan ke siswa, tingkat kesukarannya masuk ke dalam kategori sedang, perhatikan Gambar 5. 


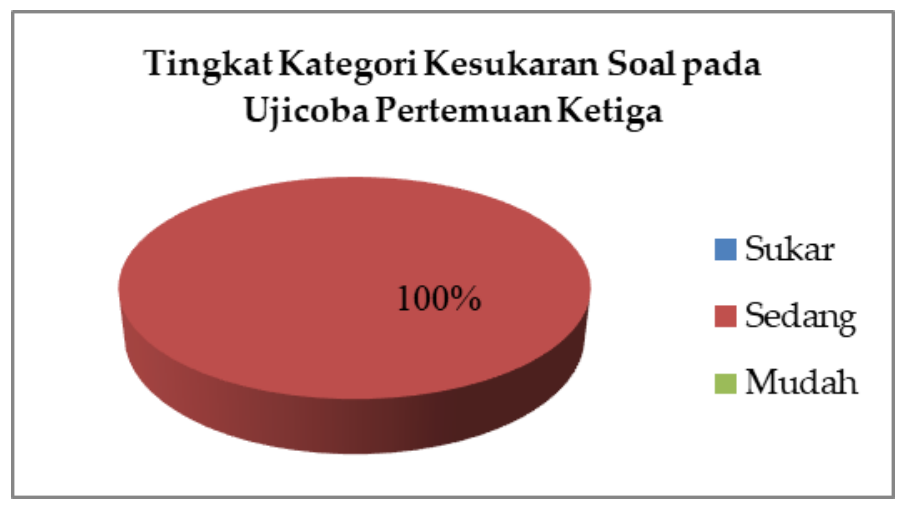

Gambar 5. Hasil Tingkat Kesukaran Soal pada Pertemuan Ketiga

Dalam melihat efektivitas soal-soal yang disampaikan melalui Kahoot! dan Quizizz, penelitian ini menggunakan tingkat kesukarannya. Berdasarkan hasil yang telah didapatkan, tingkat kesukaran soal-soal tersebut didominasi oleh tingkat kesukaran sedang. Dengan demikian, tantangan (salah satu elemen desain gim) yang disediakan oleh kedua kuis daring tersebut sebagian besar masuk ke dalam kategori sedang. Tantangan dengan tingkat kesulitan sedang seperti ini merupakan komponen penting untuk menjaga siswa tetap tertarik dan terlibat aktif dalam pengerjaan kuis (Vogel, Greenwood-Ericksen, Cannon-Bowers, \& Bowers, 2006). Jika tantangan tersebut terlalu sukar, siswa akan cenderung menyerah ketika mengerjakannya; jika tantangan tersebut terlalu mudah, siswa akan terbagi perhatiannya dan cenderung akan kehilangan minat untuk menyelesaikannya (Wang, 2008).

Berdasarkan validitas perangkat pembelajaran yang dikembangkan, efektivitas perangkat pembelajaran tersebut dalam meningkatkan minat belajar siswa, serta tingkat kesukaran soal-soal yang disampaikan melalui Kahoot! dan Quizizz, dapat disimpulkan bahwa perangkat pembelajaran tersebut secara umum berkualitas baik. Dengan demikian, perangkat pembelajaran tersebut potensial untuk diterapkan ke dalam kelas matematika yang sebenarnya agar minat belajar siswa meningkat.

Meskipun penelitian ini tujuannya adalah mengembangkan perangkat pembelajaran secara utuh (yaitu RPP, pretest, posttest, dan kuis daring), tetapi yang menjadi fokus penerapan gamifikasinya terletak pada kuis daring Kahoot! dan Quizizz. Berdasarkan hasil penelitian ini, kuis daring semacam ini merupakan alat yang efektif untuk memantik minat siswa terhadap pembelajaran matematika. Hasil ini sejalan dengan temuan beberapa penelitian lain (Göksün \& Gürsoy, 2019; Jones, Katyal, Xie, Nicolas, Leung, Noland, \& Montclare, 2019; Plump \& LaRosa, 2017). 
Elemen-elemen desain gim yang dapat difasilitasi oleh Kahoot! dan Quizizz dalam penelitian ini adalah poin, papan skor, dan tantangan. Poin diberikan ketika siswa sudah dapat menjawab soal dengan tepat. Selain itu, poin ini juga dapat menunjukkan kemajuan capaian siswa dalam melakukan aktivitas dalam kuis daring yang disediakan (Lewis, Swartz, \& Lyons, 2016). Dengan demikian, poin ini memiliki fungsi sebagai pemberi penghargaan dan penyedia umpan balik yang langsung dan berkelanjutan (Attali \& ArieliAttali, 2015; Richter, Raban, \& Rafaeli, 2015). Papan skor, atau sering disebut dengan papan peringkat, menunjukkan pemeringkatan siswa dengan perolehan poinnya. Elemen ini mengindikasikan kemajuan capaian seorang siswa relatif terhadap siswa-siswa lainnya (Landers, Bauer, \& Callan, 2017). Terakhir, soal-soal yang disampaikan melalui Kahoot! dan Quizizz dapat dianggap sebagai tantangan yang perlu diselesaikan oleh siswa. Tantangan seperti ini memfasilitasi siswa untuk menerapkan pengetahuan dan keterampilannya mengenai topik yang telah dipelajari dengan cara yang menarik dan menantang (Flores, Montoya, \& Mena, 2016). Ketiga elemen desain gim yang disediakan oleh Kahoot! dan Quizizz tersebut berpotensi untuk memenuhi kebutuhan siswa akan kompetensi dan relasi (Wee \& Choong, 2019) yang pada akhirnya akan meningkatkan kualitas belajarnya (León, Núñez, \& Liew, 2015).

Penggunaan kuis daring berbasis gamifikasi dalam penelitian ini hanya menyediakan satu contoh upaya untuk memantik minat siswa dalam pembelajaran matematika. Beberapa strategi lain juga dapat digunakan, misalnya dengan penerapan pembelajaran berbasis proyek (Bernard \& Lundgren-Cayrol, 2001; Robinson,_2013) dan penggunaan soal cerita dengan konteks yang dekat dengan minat siswa (Renninger, Ewen, \& Lasher, 2002; Setyani \& Kristanto, 2020). Selain itu, penting bagi pendidik untuk tetap menjaga minat belajar siswa dengan memberikan aktivitas-aktivitas pembelajaran yang bermakna dan berpusat siswa (Bray \& Tangney, 2016). Dengan demikian, diharapkan minat belajar siswa dalam pembelajaran matematika dapat berkembang dengan baik.

\section{Simpulan}

Perangkat pembelajaran yang dikembangkan telah memiliki kualitas yang baik dari perspektif validitasnya, potensinya dalam meningkatkan minat belajar siswa, dan tantangan (tingkat kesukaran) soal-soal kuis daringnya. Validitas perangkat ini dinilai dari penilaian yang dilakukan oleh ahli dan praktisi pembelajaran. Potensi perangkat pembelajaran tersebut dalam meningkatkan minat belajar siswa dimungkinkan dengan adanya strategi 
gamifikasi dalam kuis daring Kahoot! dan Quizizz. Terakhir, tingkat kesukaran soal-soal yang dikembangkan dalam penelitian ini memberikan tantangan yang sesuai bagi siswa untuk dapat terlibat dan berpartisipasi aktif dalam menyelesaikan soal-soal tersebut. Berdasarkan hasil penelitian ini, telah ditunjukkan bahwa gamifikasi merupakan salah satu strategi yang potensial untuk meningkatkan minat belajar siswa dalam pembelajaran matematika. Oleh karena itu, pendidik dapat mempertimbangkan strategi ini untuk diterapkan dalam pembelajaran matematika agar minat belajar belajar siswa meningkat. Akan tetapi, penelitian ini belum bisa menunjukkan elemen-elemen desain gim mana yang paling efektif untuk meningkatkan minat belajar siswa dalam pembelajaran matematika. Hal ini memberikan peluang penelitian bagi peneliti lain untuk dapat menyelidiki perbedaan pengaruh elemen-elemen desain gim (misalnya poin, tantangan, dan papan skor) terhadap minat belajar siswa.

\section{Ucapan Terima Kasih}

Kami mengucapkan terima kasih kepada Lembaga Kesejahteraan Mahasiswa Universitas Sanata Dharma yang telah mendukung sebagian pendanaan penelitian ini. Ucapan terima kasih juga kami sampaikan kepada Niluh Sulistyani, M.Pd., Eko Budi Santoso, S.J., S.Pd., Ph.D., dan Thomas Iskandar Kurniawan, S.Pd. yang telah bersedia memvalidasi perangkat pembelajaran yang telah dikembangkan.

\section{Daftar Pustaka}

Ainley, M., Hidi, S., \& Berndorff, D. (2002). Interest, learning, and the psychological processes that mediate their relationship. Journal of Educational Psychology, 94(3), 545561. https://doi.org/10.1037/0022-0663.94.3.545

Alexander, C. (2017). Student Perceptions of Gamification in Higher Education. In P. Resta \& S. Smith (Eds.), Proceedings of Society for Information Technology \& Teacher Education International Conference (pp. 1428-1433). Association for the Advancement of Computing in Education (AACE).

Attali, Y., \& Arieli-Attali, M. (2015). Gamification in assessment: Do points affect test performance? Computers $\mathcal{E}$ Education, 83, 57-63. https://doi.org/10.1016/j.compedu.2014.12.012

Basuki, Y., \& Hidayati, Y. (2019). Kahoot! or Quizizz: The Students' Perspectives. In Proceedings of the $3^{\text {rd }}$ English Language and Literature International Conference (ELLiC). Universitas Muhammadiyah Semarang.

Belbase, S. (2013). Images, Anxieties, and Attitudes toward Mathematics. International Journal of Education in Mathematics, Science and Technology, 1(4), 230-237.

Bernard, R. M., \& Lundgren-Cayrol, K. (2001). Computer Conferencing: An Environment for Collaborative Project-Based Learning in Distance Education. Educational Research and Evaluation, 7(2), 241-261. https://doi.org/10.1076/edre.7.2.241.3866

Bray, A., \& Tangney, B. (2016). Enhancing student engagement through the affordances of mobile technology: a 21st century learning perspective on Realistic Mathematics 
Education. Mathematics Education Research Journal, 28(1), 173-197. https://doi.org/10.1007/s13394-015-0158-7

Burguillo, J. C. (2010). Using game theory and Competition-based Learning to stimulate student motivation and performance. Computers \& Education, 55(2), 566-575. https://doi.org/10.1016/j.compedu.2010.02.018

Chen, C.-H., \& Chiu, C.-H. (2016). Employing intergroup competition in multitouch designbased learning to foster student engagement, learning achievement, and creativity. Computers \& Education, 103, 99-113. https://doi.org/10.1016/j.compedu.2016.09.007

Deci, E. L., Koestner, R., \& Ryan, R. M. (2001). Extrinsic Rewards and Intrinsic Motivation in Education: Reconsidered Once Again. Review of Educational Research, 71(1), 1-27. https://doi.org/10.3102/00346543071001001

Deci, E. L., \& Ryan, R. M. (1985). Intrinsic Motivation and Self-Determination in Human Behavior. Springer US. https://doi.org/10.1007/978-1-4899-2271-7

Deterding, S., Dixon, D., Khaled, R., \& Nacke, L. (2011). From game design elements to gamefulness. In A. Lugmayr, H. Franssila, C. Safran, \& I. Hammouda (Eds.), Proceedings of the 15th International Academic MindTrek Conference on Envisioning Future Media Environments - MindTrek '11 (pp. 9-15). ACM Press. https://doi.org/10.1145/2181037.2181040

Fimansyah, D. (2015). Pengaruh strategi pembelajaran dan minat belajar terhadap hasil belajar matematika. JUDIKA (Jurnal Pendidikan Unsika), 3(1), 34-44.

Flores, E. G. R., Montoya, M. S. R., \& Mena, J. (2016). Challenge-based gamification and its impact in teaching mathematical modeling. Proceedings of the Fourth International Conference on Technological Ecosystems for Enhancing Multiculturality - TEEM '16, 771776. https://doi.org/10.1145/3012430.3012605

Göksün, D. O., \& Gürsoy, G. (2019). Comparing success and engagement in gamified learning experiences via Kahoot and Quizizz. Computers \& Education, 135, 15-29. https://doi.org/10.1016/j.compedu.2019.02.015

Harackiewicz, J. M., Barron, K. E., Tauer, J. M., Carter, S. M., \& Elliot, A. J. (2000). Short-term and long-term consequences of achievement goals: Predicting interest and performance over time. Journal of Educational Psychology, 92(2), 316-330. https://doi.org/10.1037/0022$\underline{0663.92 .2 .316}$

Hidi, S. (2006). Interest: A unique motivational variable. Educational Research Review, 1(2), 6982. https://doi.org/10.1016/j.edurev.2006.09.001

Hidi, S., \& Renninger, K. A. (2006). The Four-Phase Model of Interest Development. Educational Psychologist, 41(2), 111-127. https://doi.org/10.1207/s15326985ep4102 4

Jones, S. M., Katyal, P., Xie, X., Nicolas, M. P., Leung, E. M., Noland, D. M., \& Montclare, J. K. (2019). A 'KAHOOT!' Approach: The Effectiveness of Game-Based Learning for an Advanced Placement Biology Class. Simulation \& Gaming, 50(6), 832-847. https://doi.org/10.1177/1046878119882048

Koller, O., Baumert, J., \& Schnabel, K. (2001). Does Interest Matter? The Relationship between Academic Interest and Achievement in Mathematics. Journal for Research in Mathematics Education, 32(5), 448-470. https://doi.org/10.2307/749801

Krapp, A. (1999). Interest, motivation and learning: An educational-psychological perspective. European Journal of Psychology of Education, 14(1), 23-40.

Kristanto, Y. D., Amin, S. M., \& Khabibah, S. (2016). The Development of Investigative Learning Materials Using Computer Assisted Instruction in the Topic of Reflection for Grade VII. Journal of Research and Advances in Mathematics Education, 1(2), 172-182. https://doi.org/10.23917/jramathedu.v1i2.4828

Kristanto, Y. D. (2020). Upaya Peningkatan Kualitas Pembelajaran Matematika Melalui 
Flipped Classroom dan Gamifikasi: Suatu Kajian Pustaka. PRISMA, Prosiding Seminar Nasional Matematika, 266-278.

Landers, R. N., Bauer, K. N., \& Callan, R. C. (2017). Gamification of task performance with leaderboards: A goal setting experiment. Computers in Human Behavior, 71(1), 508-515. https://doi.org/10.1016/j.chb.2015.08.008

León, J., Núñez, J. L., \& Liew, J. (2015). Self-determination and STEM education: Effects of autonomy, motivation, and self-regulated learning on high school math achievement. Learning and Individual Differences, 43, 156-163. https://doi.org/10.1016/j.lindif.2015.08.017

Lewis, Z. H., Swartz, M. C., \& Lyons, E. J. (2016). What's the Point?: A Review of Reward Systems Implemented in Gamification Interventions. Games for Health Journal, 5(2), 9399. https://doi.org/10.1089/g4h.2015.0078

Licorish, S. A., Owen, H. E., Daniel, B., \& George, J. L. (2018). Students' perception of Kahoot! 's influence on teaching and learning. Research and Practice in Technology Enhanced Learning, 13(1), 9-19. https://doi.org/10.1186/s41039-018-0078-8

Millis, K., Forsyth, C., Wallace, P., Graesser, A. C., \& Timmins, G. (2017). The Impact of Game-Like Features on Learning from an Intelligent Tutoring System. Technology, Knowledge and Learning, 22(1), 1-22. https://doi.org/10.1007/s10758-016-9289-5

O'Keefe, P. A., \& Linnenbrink-Garcia, L. (2014). The role of interest in optimizing performance and self-regulation. Journal of Experimental Social Psychology, 53(1), 70-78. https://doi.org/10.1016/j.jesp.2014.02.004

Plump, C. M., \& LaRosa, J. (2017). Using Kahoot! in the Classroom to Create Engagement and Active Learning: A Game-Based Technology Solution for eLearning Novices. Management Teaching Review, 2(2), 151-158. https://doi.org/10.1177/2379298116689783

Renninger, K. A, Ewen, L., \& Lasher, A. (2002). Individual interest as context in expository text and mathematical word problems. Learning and Instruction, 12(4), 467-490. https://doi.org/10.1016/s0959-4752(01)00012-3

Renninger, K. A. (2000). Individual interest and its implications for understanding intrinsic motivation. In C. Sansone \& J. M. Harackiewicz (Eds.), Intrinsic and Extrinsic Motivation: The Search for Optimal Motivation and Performance (pp. 373-404). Academic Press. https://doi.org/10.1016/b978-012619070-0/50035-0

Richter, G., Raban, D. R., \& Rafaeli, S. (2015). Studying Gamification: The Effect of Rewards and Incentives on Motivation. In Gamification in Education and Business (pp. 21-46). Springer International Publishing. https://doi.org/10.1007/978-3-319-10208-5 2

Robinson, J. K. (2013). Project-based learning: improving student engagement and performance in the laboratory. Analytical and Bioanalytical Chemistry, 405(1), 7-13. https://doi.org/10.1007/s00216-012-6473-x

Sailer, M., Hense, J. U., Mayr, S. K., \& Mandl, H. (2017). How gamification motivates: An experimental study of the effects of specific game design elements on psychological need satisfaction. Computers in Human Behavior, 69(1), 371-380. https://doi.org/10.1016/j.chb.2016.12.033

Sailer, M., \& Sailer, M. (2020). Gamification of in-class activities in flipped classroom lectures. British Journal of Educational Technology, bjet.12948. https://doi.org/10.1111/bjet.12948

Schraw, G., Flowerday, T., \& Lehman, S. (2001). Increasing Situational Interest in the Classroom. Educational Psychology Review, 13(3), 211-224. https://doi.org/10.1023/a:1016619705184

Senko, C., \& Harackiewicz, J. M. (2002). Performance goals: The moderating roles of context and achievement orientation. Journal of Experimental Social Psychology, 38(6), 603-610. 
https://doi.org/10.1016/s0022-1031(02)00503-6

Setyani, G. D., \& Kristanto, Y. D. (2020). A Case Study of Promoting Informal Inferential Reasoning in Learning Sampling Distribution for High School Students. SJME (Supremum Journal of Mathematics Education), 4(1), 64-77. https://doi.org/10.35706/sjme.v4i1.3132

Sugiyono. (2011). Metode Penelitian Kuantitatif, Kualitatif dan R \& D. Alfabeta.

Tosto, M. G., Asbury, K., Mazzocco, M. M. M., Petrill, S. A., \& Kovas, Y. (2016). From classroom environment to mathematics achievement: The mediating role of selfperceived ability and subject interest. Learning and Individual Differences, 50, 260-269. https://doi.org/10.1016/j.lindif.2016.07.009

Vogel, J. J., Greenwood-Ericksen, A., Cannon-Bowers, J., \& Bowers, C. A. (2006). Using Virtual Reality with and without Gaming Attributes for Academic Achievement. Journal of Research on Technology in Education, 39(1), 105-118. https://doi.org/10.1080/15391523.2006.10782475

Wang, T.-H. (2008). Web-based quiz-game-like formative assessment: Development and evaluation. Computers $\&$ Education, 51(3), 1247-1263. https://doi.org/10.1016/j.compedu.2007.11.011

Wee, S. C., \& Choong, W.-W. (2019). Gamification: Predicting the effectiveness of variety game design elements to intrinsically motivate users' energy conservation behaviour. Journal of Environmental Management, 233, 97-106. https://doi.org/10.1016/j.jenvman.2018.11.127

Zhao, F. (2019). Using Quizizz to Integrate Fun Multiplayer Activity in the Accounting Classroom. International Journal of Higher Education, 8(1), 37-43. https://doi.org/10.5430/ijhe.v8n1p37 